\title{
DESAIN PENDIDIKAN KEWIRAUSAHAAN MAHASISWA BERBASIS TECHNOPRENEURSHIP
}

\author{
Sumarno, Universitas Riau \\ sumarno.s@lecturer.unri.ac.id \\ Gimin, Universitas Riau \\ gim_unri@yahoo.co.id \\ Gani Haryana, Universitas Riau \\ gani.haryana@yahoo.com \\ Saryono, Universitas Riau \\ saryono_ur@yahoo.com
}

\begin{abstract}
ABSTRAK
Penelitian ini bertujuan untuk menyusun desain pendidikan kewirausahaan mahasiswa yang dapat menciptakan dan mengembangkan technopreneur. Penelitian dilakukan di Universitas Riau. Data dikumpulkan melalui teknik observasi, wawancara, dan dokumentasi; kemudian dianalisis secara deskriptif. Hasil penelitian menunjukkan bahwa pendidikan kewirausahaan berbasis technopreneurship memerlukan integrasi dan sinergi antara kewirausahaan dan akademik prodi/jurusan kedalam isi (materi), kegiatan, dan metode untuk membangun kompetensi kewirausahaan mahasiswa. Isi pendidikan kewirausahaan berupa materi yang disajikan, dibahas, dan dikembangkan dalam kegiatan, sedangkan kegiatan dan metodenya meliputi perkuliahan, pelatihan, pembinaan, dan lomba kewirausahaan, serta inkubasi bisnis. Perkuliahan kewirausahaan untuk menciptakan kompetensi kewirausahaan dasar (memiliki pola pikir dan kemampuan menciptakan pekerjaan), pelatihan dilaksanakan untuk menumbuhkan kompetensi kewirausahaan menengah (menyusun proposal usaha yang layak), sedangkan pembinaan dan inkubasi bisnis untuk mengembangkan kompetensi kewirausahaan lanjut (menjalankan/mengembangkan usaha). Status mata kuliah kewirausahaan perlu ditingkatkan menjadi mata kuliah wajib. Pendidikan kewirausahaan diprogramkan dan dilaksanakan oleh unit kewirausahaan berdasar Keputusan Rektor.
\end{abstract}

Kata Kunci: Pendidikan Kewirausahaan, Kewirausahaan Mahasiswa, Technopreneurship.

\begin{abstract}
This study aims to compile the student entrepreneurship education design that can create and develop technopreneur. The study was conducted at the Universitas Riau. Data were collected through observation, interview, and documentation; then analyzed descriptively. The results show that entrepreneurship education based on technopreneurship requires integration and synergy between entrepreneurship and academic courses/majors into content, activities, and methods to build student entrepreneurial competencies. The content is the material presented,
\end{abstract}


discussed, and developed in activities; while activities and methods include lectures, training, coaching, entrepreneurship competitions, and business incubation. Entrepreneurship lectures to create basic entrepreneurial competencies (having the mindset and ability to create business ideas), training and coaching to foster middle entrepreneurship competence (compile a fiasible business proposal), while coaching and business incubation to develop advanced entrepreneurial competence (running and developing business). Entrepreneurship subject should be upgraded to compulsory subject. Entrepreneurship education was programmed/implemented by entrepreneurship institutions/units based on Rector's Decree.

Keywords: Entrepreneurship Education, Student Entrepreneurship, Technopreneurship.

\section{PENDAHULUAN}

Kewirausahaan memiliki unsur utama kreatif dan inovatif (Prawirokusumo, 2010); (Suryana, 2013). Menurut hasil riset (Taatila, 2010) dan (Pajarinen, Rouvinen and Ylä-Anttila, 2006), wirausaha yang latar belakang akademiknya lebih tinggi ternyata lebih sering inovatif, menggunakan model bisnis yang modern, dan mendasarkan usaha mereka pada penggunaan teknologi baru ((Handrimurtjahjo, 2013). Hal tersebut mengimplikasikan bahwa latar belakang akademik, khususnya akademik dari pendidikan tinggi, penting bagi pembentukan dan pengembangan wirausaha. Sejalan dengan pemikiran tersebut, (Suparno, Hermawan and Syuaib, 2008) menyatakan bahwa technopreneur mampu menggabungkan antara ilmu pengetahuan yang dimiliki melalui kreasi/ide produk yang diciptakan dengan kemampuan berwirausaha melalui penjualan produk yang dihasilkan di pasar.

Hasil penelitian (Sumarno and Suarman, 2017) mengungkapkan bahwa mahasiswa Universitas Riau yang memiliki rencana usaha sesuai bidang ilmu akademiknya rata-rata hanya 5\%. Itu mengandung arti bahwa technopreneur mahasiswanya masih sangat sedikit. Hal itu disebabkan belum adanya koordinasi dan sinergi dalam program dan pelaksanaan pendidikan kewirausahaan, baik di tingkat prodi/jurusan, fakultas, maupun universitas (Sumarno and Suarman, 2017). Oleh karenanya pendidikan kewirausahaan mahasiswa perlu dikembangkan dalam satu sistem terintegrasi mulai dari tingkat prodi/jurusan hingga universitas serta unit-unit pendukungnya dengan melibatkan semua dosen, baik dosen kewirausahaan maupun dosen nonkewirausahaan. Untuk mendapat solusi tersebut, perlu desain pendidikan kewirausahaan bagi mahasiswa di perguruan tinggi, khususnya di Universitas Riau. Melalui desain pendidikan kewirausahaan tersebut diharapakan jumlah mahasiswa yang memiliki kreativitas dan inovasi berdasarkan ilmu pengetahuan prodi/jurusannya dapat meningkat dan berkembang. Akhirnya produktivitas masyarakat lokal dan nasional dapat meningkat secara berkelanjutan dan lebih berdaya saing. Masalah yang perlu dipecahkan adalah bagaimana desain pendidikan kewirausahaan mahasiswa Universitas Riau yang dapat menciptakan dan atau mewujudkan serta mengembangkan technopreneur mereka? 
Menurut Center for Entrepreneurial Leadership Clearinghouse on Entrepreneurship Education ((Handrimurtjahjo, 2013), pendidikan kewirausahaan merupakan proses menyediakan konsep dan keterampilan bagi individu untuk mengenali peluang yang orang lain abaikan, dan untuk memiliki wawasan, harga diri dan pengetahuan untuk bertindak dimana orang lain raguragu. Lebih spesifik (Fayolle, 2009) mengemukakan pendidikan kewirausahaan sebagai aktivitas yang ditujukan untuk terjadinya proses kewirausahaan, yaitu mulai dari menumbuhkan pola pikir dan sikap serta keterampilan kewirausahaan sehingga dapat membangkitkan ide/gagasan usaha, kemudian memulai usaha dan mengembangkannya melalui inovasi. Secara lebih rinci (Rasmussen, Moberg and Revsbech, 2015), mengungkapkan bahwa pendidikan kewirausahaan mencakup unsur isi, metode, dan aktivitas untuk pengembangan motivasi, kompetensi, dan pengalaman agar peserta dapat menerapkan, mengelola, dan berpartisipasi dalam proses pemberian nilai tambah. Dari pengertian pendidikan kewirausahaan yang dikemukakan di atas, dapat dirangkum bahwa pendidikan kewirausahaan adalah segenap isi, metode, dan aktivitas untuk mengembangkan pola pikir, sikap, motivasi, pengetahuan, keterampilan, serta pengalaman kewirausahaan, sehingga individu mampu menemukan ide/gagasan usaha untuk meraih peluang, memulai usaha, dan mengembangkan usaha yang dapat memberikan nilai tambah bagi dirinya dan atau orang lain. Pengertian tersebut menunjukkan bahwa pendidikan kewirausahaan memiliki cakupan: isi, metode, dan aktivitas. Cakupan tersebut ditujukan untuk memberikan/mengembangkan pengetahuan, pola pikir, sikap, motivasi, keterampilan, dan pengalaman kewirausahaan. Cakupan dan tujuan tersebut dimaksudkan untuk mendapatkan individu yang mampu menciptakan ide/gagasan usaha hingga mengembangkan usahanya bagi pemberian nilai tambah bagi dirinya dan atau orang lain.

Berkenaan pendidikan kewirausahaan mahasiswa, (Handrimurtjahjo, 2013) mengungkapkan, di perguruan tinggi tertentu, pendidikan kewirausahaan dilaksanakan dalam 4 (empat) tahap yaitu tahun pertama (creativity program), tahun kedua (foundation program), tahun ketiga (establishing entrepreneurship program) dan tahun ke-empat (hatchery program). Tahun pertama sampai tahun kedua, pesertanya adalah seluruh mahasiswa program studi manajemen/bisnis, sedangkan tahun ketiga dan tahun keempat pesertanya adalah mahasiswa terpilih yang memiliki karakter dan motivasi tinggi dalam kewirausahaan serta penetapan usaha baru (start-up new venture). Secara lebih rinci, (Kodrat and Christina, 2015) mengemukakan proses untuk menciptakan entreprenur melalui pendidikan di Fakultas Ekonomi Universitas Ciputra. Proses pendidikan kewirausahaan yang dilakukan melalui tahapan: 1) membangkitkan inspirasi mahasiswa untuk menanamkan pola pikir (dilakukan pada semester 1); melatih kemampuan melihat peluang, kreativitas, dan mengkalkulasikan risiko, keterampilan memimpin; dan mengembangkan jejaring bisnis mahasiswa (dilakukan pada semester 1 hingga semester 7). Untuk melatih dan atau mengembangkan kreativitas, dapat dilakukan melalui 4P yaitu: 1) Pembentukan pribadi kreatif, 2) Motivasi Pendorong kreativitas, 3) Proses kreativitas, dan 4) Produk kreatif. Menurut (Gasse and Tremblay, 2006) dalam penelitiannya di Universitas Kanada, untuk mempromosikan kewirausahaan dan meningkatkan penggunaan kapasitas kreatif yang telah menjadi 
bagian dari lingkungan universitas dapat dilakukan melalui faktor-faktor yang berupa: menampilkan sikap positif terhadap kewirausahaan, mengungkapkan persetujuan program universitas dan media, menyajikan kewirausahaan sebagai gaya hidup, mempromosikan sukses kewirausahaan melalui pengakuan sosial dan kehormatan, memperkuat bakat, mengawasi keluar untuk kesempatan, dan termasuk penemuan, penemuan dan risiko dalam konten pedagogi.

Suparno, Hermawan dan Syuaib (2008) mengungkapkan bahwa technopreneurship merupakan gabungan dari teknologi dengan kewirausahaan. Dalam undang-undang perguruan tinggi dinyatakan bahwa teknologi adalah penerapan dan pemanfaatan berbagai cabang Ilmu Pengetahuan yang menghasilkan nilai bagi pemenuhan kebutuhan dan kelangsungan hidup, serta peningkatan mutu kehidupan manusia (Undang-Undang Republik Indonesia Nomor 12 Tahun 2012 Tentang Pendidikan Tinggi, 2012). Dari kedua hal tersebut, technopreneurship dapat diartikan sebagai proses kemampuan kreatif dan inovatif melalui penerapan dan pemanfaatan ilmu pengetahuan untuk menjalankan kegiatan usaha yang memberikan nilai tambah bagi dirinya dan atau orang lain. Menurut Direktorat Akademik, technopreneur mendasarkan ke-enterpreneuran-nya berdasarkan keahlian yang berbasis pendidikan dan pelatihan yang didapatkannya di bangku perkuliahan ataupun percobaan pribadi (Dit. Akademik Ditjen. Dikti Kemdiknas, 2008). Technopreneur mampu menggabungkan antara ilmu pengetahuan yang dimiliki melalui kreasi/ide produk yang diciptakan dengan kemampuan berwirausaha melalui penjualan produk yang dihasilkan di pasar (Suparno, Hermawan and Syuaib, 2008).

Literatur atau artikel tentang pendidikan kewirausahaan yang ada baru mengemukakan konsep-konsep pendidikan kewirausahaan secara umum tetapi belum mengungkapkan desain model pendidikan kewirausahaannya. Begitu juga literatur atau artikel tentang technopreneur yang umumnya hanya mengemukakan konsep-konsep tentang technopreneur. Penelitian ini mencoba menyusun desain pendidikan kewirausahaan yang berbasis technoprenenurship.

\section{METODE PENELITIAN}

Penelitian ini dilakukan di Universitas Riau yang mencakup kegiatan kuliah kewirausahaan, kegiatan-kegiatan penunjang kewirausahaan, dan unitunit atau lembaga yang terlibat dalam pengelolaan/pelaksanaan pendidikan kewirausahaan. Responden penelitian yaitu pimpinan universitas, fakultas, jurusan/prodi, unit atau lembaga yang terlibat dalam pendidikan kewirausahaan; dosen pengampu mata kuliah kewirausahaan; serta mahasiswa. Pengumpulan data dilakukan melalui teknik observasi, wawancara, dan dokumentasi. Observasi untuk mengumpulkan data tentang pelaksanaan perkuliahan dan kegiatan penunjang/pendukung kewirausahaan; wawancara digunakan untuk mengumpulkan data tentang kebijakan-kebijakan yang berkaitan dengan pendidikan kewirausahaan dan pelaksanaannya; sedangkan dokumentasi digunakan untuk mengumpulkan data tentang hasil yang diperoleh dari kegiatan pendidikan kewirausahaan. Data penelitian dianalisis 
dengan menggunakan teknik analisis deskriptif baik kuantitatif maupun kualitatif.

\section{HASIL PENELITIAN DAN PEMBAHASAN}

Keberadaan mata kuliah kewirausahaan dan pelaksanaan perkuliahannya di Universitas Riau sangat bervariasi dan sangat tergantung pada political-will pimpinan fakultas dan atau jurusan/prodi untuk mengadakan/menerapkan mata kuliah kewirausahaan dalam kurikulumnya. Hal itu disebabkan oleh kebijakan universitas tentang mata kuliah Kewirausahaan yang masih berstatus sebagai mata kuliah pilihan. Akibatnya jumlah mahasiswa pada fakultas atau jurusan atau prodi yang tidak menerapkan mata kuliah Kewirausahaan, yang mengikuti kegiatan pendidikan kewirausahaan di tingkat universitas sangat sedikit. Mereka juga hanya dengan bekal wawasan, pengetahuan, dan keterampilan yang sangat minim dibandingkan mahasiswa dari prodi/jurusan yang melaksanakan kuliah kewirausahaan. Hal demikian dapat dimaklumi karena kewirausahaan tidak semata-mata muncul dari adanya bakat tetapi dapat dipelajari ((Alma, 2010). Untuk terwujudnya kebersamaan dalam menciptakan lulusan yang memiliki wawasan dan pengetahuan kewirusahaan, perlu adanya kebijakan yang lebih jelas tentang mata kuliah Kewirausahaan, misalnya menjadi mata kuliah Wajib. Adanya kewirausahaan menjadi mata kuliah Wajib, lebih jauh diharapkan akan meningkatkan kreatifitas dan daya saing mahasiswa/lulusan supaya cepat mendapatkan pekerjaan (melalui penciptaan kerja). Hal itu sesuai dengan salah satu fungsi pendidikan tinggi yaitu mengembangkan sivitas akademika yang inovatif, responsif, kreatif, terampil, berdaya saing, dan kooperatif (Undang-Undang Republik Indonesia Nomor 12 Tahun 2012 Tentang Pendidikan Tinggi, 2012). Status mata kuliah kewirausahaan sebagai mata kuliah pilihan juga membawa implikasi pada perbedaan isi mata kuliah. Ada yang hanya menitik beratkan atau fokus pada pemberian wawasan dan perubahan pola pikir mahasiswa kearah kewirausahaan, ada juga yang sampai membekali keterampilan kewirausahaan, hingga ada yang praktik kewirausahaan walaupun hanya sekedar berjualan produk.

Kegiatan kewirausahaan non-kuliah di Universitas Riau dilaksanakan mulai dari tingkat prodi/jurusan hingga tingkat universitas. Pada tingkat prodi/jurusan, kegiatan kewirausahaan non-kuliah sangat tergantung pada kemauan dosen kewirausahaan dan kordinator prodi ataupun ketua jurusan. Tidak semua prodi/jurusan mengadakan kegiatan pendukung kuliah kewirausahaan; walaupun memiliki mata kuliah kewirausahaan dalam kurikulumnya. Hal ini juga sebagai akibat dari status mata kuliah kewirausahaan yang masih sebagai mata kuliah pilihan dan belum adanya arah yang jelas tentang kegiatan kewirausahaan. Efek yang terjadi yaitu masih ada prodi/jurusan yang memandang tidak perlu ada kegiatan penunjang kewirausahaan, terlebih bagi prodi/jurusan yang belum memiliki mata kuliah kewirausahaan. Akibatnya mahasiswa kurang memiliki keterampilan dan pengalaman dalam praktik kewirausahaan, dan belum memiliki makna yang jelas bagi kepentingan kehidupan mahasiswa ataupun lulusan. 
Hal lain yang belum diberdayakan secara optimal untuk pelaksanaan dan pengembangan kewirausahaan (khususnya kegiatan non kuliahnya) adalah kegiatan kemahasiswaan. Salah satu unit kegiatan kemahasiswaan yang merupakan perwujudan praktik kewirausahaan mahasiswa adalah Koperasi Mahasiswa (Kopma). Fungsi koperasi di perguruan tinggi yang harus dikembangkan adalah pendidikan dan pelatihan entrepreneur guna melahirkan wirausaha baru yang mampu membawa kemajuan koperasi dan masyarakat (Bondan, 2014). Kopma di Universitas Riau secara kelembagaan sudah ada sejak tahun 1980-an, namun secara fungsional keberadaannya saat ini belum sesuai dengan harapannya. Organisasi dan kegiatannya belum sepenuhnya sesuai dengan prinsip dan azas koperasi, sehingga belum berfungsi sepenuhnya sebagai wadah gerakan kewirausahaan mahasiswa. Untuk ini perlu ada kebijakan universitas yang dapat memfasilitasi terjadinya reorientasi dan reposisi serta reorganisasi Kopma Universitas Riau, sehingga dapat berfungsi sebagai pencipta/pengembanga wirausaha dari kalangan mahasiswa/alumninya.

Organisasi formal kemahasiswaan Universitas Riau, baik di tingkat prodi (Himpunan Mahasiswa Prodi/Jurusan) maupun di tingkat fakultas dan universitas (Badan Eksekutif Mahasiswa), belum diberdayakan untuk pengembangan budaya dan praktik kewirausahaan. Bidang-bidang yang ada dalam organisasi tersebut belum sepenuhnya memiliki bidang khusus yang menangani kewirausahaan mahasiswa. Padahal kegiatan kewirausahaan sebenarnya dapat menjadi bagian dari unit-unit kegiatan kemahasiswaan yang ada, khususnya dalam organisasi formal kemahasiswaan yang ada di tingkat prodi (Himpunan Mahasiswa Prodi/Jurusan) sampai pada tingkat universitas (Badan Eksekutif Mahasiswa). Pada organisasi tersebut dapat dimasukkan bidang kewirausahaan.

Pemanfaatan ilmu pengetahuan prodi/jurusan sebagai bekal kreativitas dan inovasi usaha mahasiswa Universitas Riau masih rendah. Hal ini disebabkan dosen mata kuliah prodi (dosen non-kewirausahaan) masih belum sepenuhnya mengembangkan daya/kemampuan kreativitas mahasiswa dalam ilmu pengetahuan prodi/jurusannya; terlebih untuk ke arah ide-ide bisnis (Sumarno and Suarman, 2017), padahal kewirausahaan memiliki unsur inti kreatifitas dan inovasi (Prawirokusumo, 2010) dan (Suryana, 2013). Di sini peran dosen mata kuliah prodi menjadi sangat penting untuk menumbuhkembangkan daya/kemampuan kreativitas mahasiswanya dalam lingkup ilmu pengetahuan prodi/jurusannya. Untuk itu pengembangan kewirausahaan mahasiswa tidak hanya melalui kuliah dan kegiatan kewirausahaan semata, melainkan perlu adanya sinergitas dengan dosen nonkewirausahaan, terutama dosen mata kuliah prodi/jurusan.

Selain kuliah dan kegiatan pendukung kuliah kewirausahaan yang belum memadai dan belum dioptimalkan, koordinasi pengelolaan kewirausahaan mahasiswa, baik kuliah maupun kegiatan pendukungnya, juga belum jelas. Pada tingkat universitas belum ada arah dan tujuan yang jelas tentang kewirausahaan mahasiswa. Masing-masing fakultas yang menyelenggarakan kuliah kewirausahaan dan kegiatan pendukungnya belum memiliki acuan yang jelas dalam menentukan kebijakan, tujuan, dan pengelolaan kewirausahaannya; begitu juga jurusan dan prodinya. Penempatan Pusat Pengembangan Karir dan Kewirausahaan (P2K2) dibawah Lembaga Pengembangan dan Penjaminan 
Mutu Pendidikan (LPPMP), di satu sisi sudah dapat dipandang memadai karena berkenaan dengan pengelolaan/penyelenggaraan pendidikan kewirausahaan. Pada sisi yang lain, tugas pokok dan fungsi (tupoksi) P2K2 berkenaan dengan pelaksanaan kegiatan kewirausahaan yang langsung bersinggungan dengan mahasiswa/alumni. Kegiatan-kegiatan praktis kemahasiswaan (termasuk kegiatan kewirausahaannya) di Universitas Riau berada pada lingkup tugas dan fungsi Wakil Rektor Bidang Kemahasiswaan dan Alumni (WR3) sehingga P2K2, dari sisi ini, lebih dekat dengan tupoksi operasionalnya WR3. Untuk memperjelas kedudukan ini, tupoksi penyelenggaraan pendidikan kewirausahaan yang berupa kuliah kewirausahaan sebenarnya dapat diserahkan kepada unit Mata Kuliah Wajib Umum (MKWU) yang berada di bawah koordinasi LPPMP, sedangkan P2K2 diposisikan sebagai unit operasionalnya WR3 karena akan menjalankan tupoksi pengembangan karir dan kewirausahaan mahasiswa sebagai bagian yang sangat dekat dengan tupoksinya WR3.

Berdasarkan pada hasil dan pembahasan di muka tentang kuliah kewirausahaan, pemanfaatan ilmu akademik prodi/jurusan (terkait kuliah nonkewirausahaan), kegiatan pendukung kewirausahaan, optimalisasi unit kegiatan kemahasiswaan, dan kordinasi pengelolaan kegiatan kewirausahaan secara keseluruhan, pendidikan kewirausahaan di Universitas Riau dapat dirancang seperti ditunjukkan melalui Gambar 1 berikut ini.

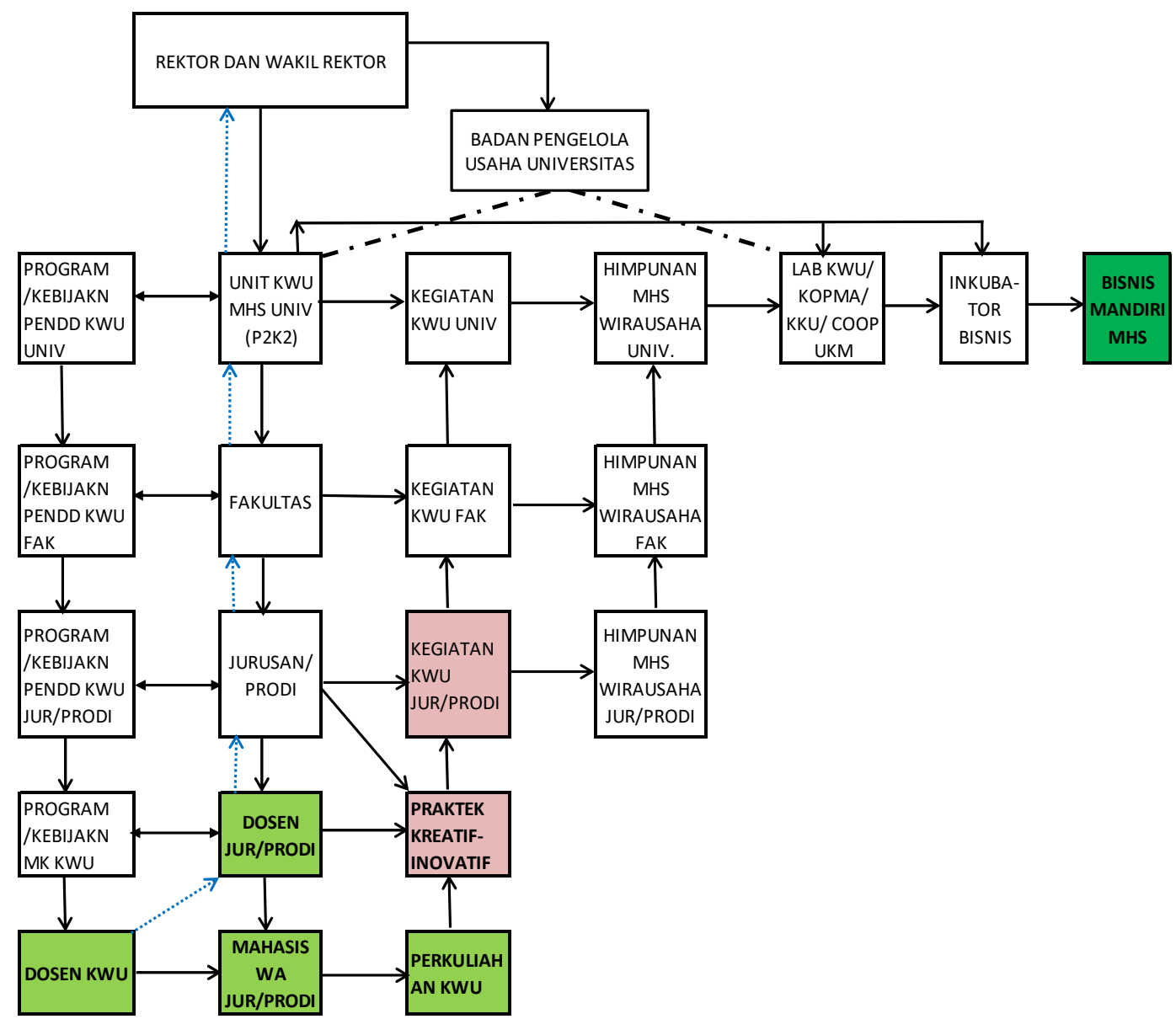

Gambar 1. Desain Pendidikan Kewirausahaan Berbasis Technopreneurship 
Desain atau rancangan pendidikan kewirausahaan berbasis technopreneurship tersebut dapat dijelaskan seperti berikut.

\section{Arti dan komponen pendidikan kewirausahaan}

Pendidikan kewirausahaan diartikan sebagai integrasi dan sinergi dari isi, aktivitas, dan metode untuk mengembangkan wawasan, pola pikir, sikap, motivasi, pengetahuan, keterampilan, serta pengalaman kewirausahaan, sehingga individu mampu menemukan ide/gagasan usaha untuk meraih peluang, memulai usaha, dan mengembangkan usaha yang dapat memberikan nilai tambah bagi dirinya dan atau orang lain. Integrasi dan sinergi yaitu penyatuan atau perpaduan berbagai komponen untuk bersama-sama saling memberikan kontribusi dan manfaat sehingga tercipta daya atau kekuatan yang lebih optimal dalam/untuk menciptakan, menumbuhkan, dan mengembangkan kompetensi kewirausahaan peserta didik.

Isi yaitu materi beserta keluasan dan kedalaman yang akan diberikan, dibahas, dikembangkan, dan atau dipraktekkan dalam pendidikan untuk menciptakan, menumbuhkan, dan mengembangkan kompetensi kewirausahaan peserta didik atau tujuan pendidikan kewirausahaan. Aktivitas yaitu kegiatan untuk memberikan, membahas, dan atau mengembangkan materi pendidikan agar kompetensi kewirausahaan peserta didik atau tujuan pendidikan kewirausahaan dapat tercipta, tumbuh, dan berkembang.

Metode berkenaan dengan cara atau teknik dalam melaksanakan aktivitas agar kompetensi kewirausahaan peserta didik atau tujuan pendidikan kewirausahaan dapat dicapai, ditumbuhkan, dan dikembangkan secara lebih efektif dan efisien. Wawasan, pola pikir, sikap, dan motivasi kewirausahaan yaitu kompetensi kewirausahaan peserta didik ranah afektif yang harus diciptakan, ditumbuhkan, dan dikembangkan agar mereka memiliki pola pikir, sikap berani, dan semangat juang untuk menciptakan pekerjaan (job creator), bukan mencari pekerjaan (job seeker).

Pengetahuan dan keterampilan kewirausahaan yaitu kompetensi kewirausahaan peserta didik ranah kognitif dan ranah psikomotor yang harus diciptakan, ditumbuhkan, dan dikembangkan agar mereka memiliki pengetahuan dan keterampilan yang memadai untuk menciptakan ide bisnis, menyusun kelayakan bisnis, menjalankan bisnis, dan mengembangkan bisnisnya. Menciptakan ide bisnis, menyusun kelayakan bisnis dapat dikategorikan sebagai kompetensi kewirausahaan tingkat dasar; menjalankan bisnis baru dapat dikategorikan sebagai kompetensi kewirausahaan menengah; dan mengembangkan bisnis dapat dikategorikan sebagai kompetensi kewirausahaan tingkat lanjut.

Pengalaman kewirausahaan yaitu tindakan nyata atau mengalami dalam kejadian/peristiwa nyata sebagai praktik penerapan pengetahuan dan atau keterampilan kewirausahaan. Nilai tambah yaitu manfaat yang diperoleh/dirasakan individu dan atau masyarakat dari suatu usaha yang dijalankan dan atau dikembangkan.

\section{Materi pendidikan kewirausahaan}

Materi pendidikan kewirausahaan keluasannya mencakup materi untuk kompetensi kewirausahaan ranah afektif, ranah kognitif, dan ranah psikomotor. 
Kedalaman materi tersebut disesuaikan dengan tingkat kompetensi kewirausahaan yang akan dicapai. Tingkatan kompetensi kewirausahaan yang akan dicapai terdiri dari kompetensi kewirausahaan dasar, kompetensi kewirausahaan menengah, dan kompetensi kewirausahaan lanjut.

Materi untuk kompetensi kewirausahaan dasar, arah utamanya untuk menanamkan atau menciptakan kompetensi kewirausahaan ranah afektif, kognitif, dan psikomotor. Materi untuk kompetensi kewirausahaan menengah, arah utamanya untuk menumbuhkan kompetensi kewirausahaan ranah afektif, kognitif, dan psikomotor; sedangkan materi untuk kompetensi kewirausahaan lanjutan, arah utamanya untuk mengembangkan kompetensi kewirausahaan ranah afektif, kognitif, dan psikomotor.

Materi untuk penanaman, penumbuhan, dan pengembangan kompetensi afektif kewirausahaan mencakup materi untuk menanamkan dan menumbuhkembangkan wawasan, pola pikir, sikap, dan motivasi kewirausahaan mahasiswa. Materi untuk penanaman, penumbuhan, dan pengembangan kompetensi kognitif dan psikomotor kewirausahaan mencakup materi untuk menanamkan dan menumbuhkembangkan pengetahuan dan keterampilan serta pengalaman kewirausahaan mahasiswa.

Materi untuk penanaman atau penciptaan kompetensi kewirausahaan mahasiswa (kompetensi kewirausahaan dasar) dikemas dalam kerangka mata kuliah. Materi untuk penumbuhan kompetensi kewirausahaan (kompetensi kewirausahaan menengah) dikemas dalam kerangka pelatihan dan pembinaan; sedangkan materi untuk pengembangan kompetensi kewirausahaan (kompetensi kewirausahaan lanjutan) dikemas dalam kerangka pelatihan dan pembinaan kewirausahaan, serta inkubasi bisnis. Status mata kuliah kewirausahaan ditingkatkan menjadi mata kuliah wajib umum (MKWU). Mata kuliah tersebut berisi materi konseptual aplikatif dan praktik yang memiliki satuan kredit semester (SKS) minimal 3 (tiga) SKS. Mata kuliah diadakan dan dilaksanakan oleh prodi/jurusan.

Materi pelatihan dan pembinaan kewirausahaan serta inkubasi bisnis disusun dalam kerangka kurikulum pengembangan bisnis mahasiswa untuk memperjelas cakupan dan tingkatan yang lebih spesifik. Pelatihan dan pembinaan kewirausahaan serta inkubasi bisnis diadakan dan dilaksanakan oleh fakultas dan atau unit kewirausahaan universitas.

\section{Kegiatan dan metode pendidikan kewirausahaan}

Kegiatan dan metode untuk penanaman atau penciptaan kompetensi kewirausahaan (tingkat kompetensi kewirausahaan dasar) yang berupa penanaman wawasan, pola pikir, motivasi, pengetahuan, keterampilan, dan praktik kewirausahaan dasar berupa kegiatan perkuliahan yang dilaksanakan di tingkat prodi/jurusan. Perkuliahan dilaksanakan secara konseptual aplikatif dan praktik yang mencakup kegiatan kuliah konsep/teori dan praktik. Praktik dapat dilakukan di kampus dan atau di luar kampus.

Perkuliahan kewirausahaan mengintegrasikan dan mensinergikan isi mata kuliah kewirausahaan dan isi mata kuliah prodi/jurusan, untuk mengembangkan pengetahuan dan keterampilan kreatif serta praktik pengalaman kewirausahaan mahasiswa yang berbasis ilmu akademik prodi/jurusannya. Integrasi dan sinerginya dilaksanakan dalam kuliah 
konsep/teoretik maupun praktiknya. Ini sejalan dengan pendapat (Galus, 2009) yang menyatakan bahwa program pengembangan kewirausahaan diharapkan menjadi wahana pengintegrasian secara sinergi antara penguasaan sains dan teknologi dengan jiwa kewirausahaan.

Perkuliahan dievaluasi secara komprehensif baik persiapannya, pelaksanaannya, ouput-nya, maupun outcome-nya. Persiapan dievaluasi melalui perangkat perkuliahan yang mencakup silabus, kontrak kuliah, rencana perkuliahan semester, dan instrumen penilaiannya. Proses perkuliahan dievaluasi melalui monitoring pelaksanaan kuliah. Output perkuliahan dinilai dari proposal rencana usaha yang dihasilkan mahasiswa. Evaluasi output perkuliahan diintegrasikan dan disinergikan dengan Program Kreativitas Mahasiswa bidang Kewirausahaan (PKM-K). Outcome perkuliahan dievaluasi melalui usaha yang dijalankan dan atau dikembangkan mahasiswa/lulusan. Evaluasi outcome diintegrasikan dan disinergikan dengan program Kompetisi Bisnis Mahasiswa Indonesia (KBMI).

Praktik kewirausahaan dasar di tingkat prodi/jurusan dapat berupa ajang kreatifitas prodi/jurusan. Hasil praktik ini diintegrasikan dan disinergikan dengan organisasi kemahasiswaan di tingkat prodi/jurusan bidang kewirausahaan. Integrasi dan sinergi pada tingkat ini membentuk Himpunan Mahasiswa Wirausaha Prodi/Jurusan. Himpunan ini mewadahi mahasiswa yang menjalankan PKM-K dan KBMI serta praktik kewirausahaan lainnya.

Kegiatan untuk penumbuhan kompetensi kewirausahaan menengah (tingkat kompetensi kewirausahaan menengah) yang berupa penumbuhan wawasan, pola pikir, motivasi, pengetahuan, keterampilan, dan kemampuan mendirikan/memulai usaha berupa kegiatan pelatihan, lomba, dan pembinaan kewirausahaan. Kegiatan tersebut dilaksanakan oleh fakultas atau unit kewirausahaan universitas atau sinergi keduanya.

Pelatihan dilaksanakan dalam bentuk workshop yang menitik beratkan pada praktik atau demonstrasi dari pengetahuan maupun keterampilan spesifik atau teknis kewirausahaan. Praktik dapat dilakukan di kampus dan atau di luar kampus. Lomba kewirausahaan dilaksanakan untuk penumbuhan kompetensi kewirausahaan dilaksanakan di tingkat fakultas dengan peserta perwakilan dari setiap prodi/jurusan yang ada di fakultas masing-masing. Pembinaan dilaksanaan dalam bentuk bimbingan dan atau konsultansi teknis kewirausahaan sesuai kebutuhan peserta didik baik sebelum maupun sesudah lomba kewirausahaan.

Pelatihan dan pembinaan mengintegrasikan dan mensinergikan isi pelatihan dengan ilmu akademik prodi/jurusan untuk mengembangkan praktik kreatif serta pengalaman praktis kewirausahaan mahasiswa yang berbasis ilmu akademik prodi/jurusannya. Integrasi dan sinerginya dilaksanakan dalam proses kreatif maupun praktiknya. Pelatihan dan pembinaan dievaluasi secara komprehensif baik persiapannya, pelaksanaannya, ouput-nya, maupun outcome-nya. Persiapan dievaluasi melalui isi, narasumber, dan instrumen penilaiannya. Proses pelatihan dan pembinaan dievaluasi melalui monitoring pelaksanaan pelatihan dan pembinaan. Output pelatihan dan pembinaan dievaluasi dari proposal rencana usaha yang dihasilkan mahasiswa untuk program KBMI atau proposal usaha untuk kompetisi lainnya atau dari hasil pretest dan posttest pelatihan/pembinaan. Outcome kegiatan penumbuhan 
kompetensi kewirausahaan dievaluasi melalui jumlah mahasiswa yang menjalankan usaha dari program KBMI lolos ataupun kewirausahaan lainnya.

Lomba kewirausahaan dilaksanakan untuk memantapkan dan mengevaluasi hasil pelatihan dan pembinaan. Hasil dari lomba kewirausahaan ataupun penumbuhan kompetensi kewirausahaan menengah di tingkat fakultas diintegrasikan dan disinergikan dengan organisasi kemahasiswaan tingkat fakultas bidang kewirausahaan. Integrasi dan sinergi pada tingkat ini membentuk Himpunan Mahasiswa Wirausaha Fakultas. Himpunan ini mewadahi mahasiswa yang menjalankan KBMI serta praktik kewirausahaan lainnya.

Kegiatan untuk pengembangan kompetensi kewirausahaan lanjut (tingkat kompetensi kewirausahaan lanjut) yang berupa pengembangan wawasan, pola pikir, motivasi, pengetahuan, keterampilan, dan kemampuan mengembangkan usaha berupa kegiatan pelatihan dan pembinaan kewirausahaan, inkubasi bisnis, dan lomba kewirausahaan tingkat universitas. Kegiatan tersebut dikelola dan dilaksanakan oleh unit kewirausahaan universitas. Pelatihan dilaksanakan dalam bentuk workshop yang menitik beratkan pada praktik atau demonstrasi dari pengetahuan maupun keterampilan spesifik atau teknis kewirausahaan untuk pengembangan usaha. Praktik pelatihan/pembinaan melibatkan usaha peserta. Pembinaan dilaksanaan dalam bentuk bimbingan dan atau konsultansi teknis kewirausahaan sesuai kebutuhan peserta dan atau inisiatif pembina. Inkubasi bisnis dilaksanakan dalam bentuk fasilitasi oleh unit kewirausahaan universitas, baik tempat usaha, manajemen, produksi, pemasaran, ataupun pendanaan. Lomba kewirausahaan tingkat universitas dilaksanakan dalam bentuk ajang kompetisi pengelolaan dan pengembangan usaha baik produk, proses produksi, pasar dan pemasaran, ataupun manajemen organisasi usahanya.

Pelatihan, pembinaan, inkubasi, dan lomba kewirausahaannya tetap mengintegrasikan dan mensinergikan isinya dengan ilmu akademik prodi/jurusan untuk mengembangkan usaha serta pengalaman praktis mahasiswa yang berbasis ilmu akademik prodi/jurusannya. Integrasi dan sinerginya dilaksanakan dalam proses pelatihan, pembinaan, maupun inkubasinya.

Pelatihan, pembinaan, dan inkubasi dievaluasi secara komprehensif baik persiapannya, pelaksanaannya, ouput-nya, maupun outcome-nya. Persiapan dievaluasi melalui isi, narasumber, dan instrumen penilaiannya, serta fasilitas inkubasi yang tersedia). Proses pelatihan, pembinaan, dan inkubasi dievaluasi melalui monitoring pelaksanaan pelatihan, pembinaan, dan inkubasi. Output pelatihan, pembinaan, dan inkubasi dinilai dari proposal rencana pengembangan usaha yang dihasilkan mahasiswa untuk program Expo Kewirausahaan Mahasiswa Indonesia (Expo KMI) ataupun dari hasil pretest dan posttest pelatihan/pembinaan. Output inkubasi dievaluasi melalui omset penjualan dan laba usaha saat masuk inkubasi dan setelah proses inkubasi. Outcome kegiatan pengembangan dievaluasi melalui jumlah mahasiswa yang mendapatkan juara dalam Expo KMI ataupun kejuaraan kewirausahaan lainnya.

Lomba kewirausahaan tingkat universitas dilaksanakan untuk memantapkan dan mengevaluasi hasil pelatihan, pembinaan, dan inkubasi 
bisnis. Hasil dari lomba kewirausahaan ataupun pengembangan kompetensi kewirausahaan lanjutan di tingkat universitas diintegrasikan dan disinergikan dengan organisasi kemahasiswaan tingkat universitas bidang kewirausahaan serta koperasi mahasiswa (Kopma). Integrasi dan sinergi pada tingkat ini membentuk Himpunan Mahasiswa Wirausaha Universitas. Himpunan ini mewadahi mahasiswa yang memenangkan kejuaraan menjalankan usaha, baik Expo KMI maupun kejuaraan kewirausahaan lainnya.

\section{Kebijakan Program Pendidikan Kewirausahaan}

Pendidikan kewirausahaan mahasiswa berbasis technopreneurship dikelola dalam bentuk program dan kebijakan. Program utamanya (technopreneurship grand program) ditetapkan melalui kebijakan univesitas (Keputusan Rektor). Grand program pendidikan kewirausahaan disusun berdasarkan visi misi universitas dan masukan dari unit kewirausahaan universitas, fakultas, unit kewirausahaan mahasiswa, dan pihak berkepentingan lainnya. Perencanaan dan pelaksanaan program tersebut diberikan kewenangan dan tanggungjawabnya kepada unit kewirausahaan universitas.

Berdasarkan program dan kebijakan kewirausahaan universitas, fakultas menyusun program dan kebijakan kewirausahaan fakultas dengan melibatkan jurusan dan unit kemahasiswaan fakultas serta pihak berkepentingan lainnya. Program dan kebijakan kewirausahaan fakultas menjadi acuan jurusan untuk menyusun program dan kebijakan kewirausahaannya. Penyusunan program dan kebijakan kewirausahaan melibatkan prodi dan unit kemahasiswaan jurusan serta pihak berkepentingan lainnya. Selanjutnya prodi menyusun program dan kebijakan kewirausahaanya berdasarkan program kebijakan jurusan. Penyusunannya melibatkan dosen prodi (baik dosen kewirausahaan maupun dosen non-kewirausahaan) dan unit mahasiswa prodi serta pihak berkepentingan lainnya. Akhirnya dosen kewirausahaan menyusun program perkuliahan kewirausahaan berdasar program kebijakan prodi dengan mengintegrasikan isi mata kuliah bidang prodinya. Begitu juga dosen non kewirausahaan menyusun integrasi kewirausahaan dalam program perkuliahannya.

\section{SIMPULAN}

Berdasarkan hasil penelitian dan pembahasan serta rancangan pendidikan kewirausahaan dapat diambil kesimpulan berupa: 1) Pendidikan kewirausahaan diartikan sebagai integrasi dan sinergi dari isi, aktivitas, dan metode untuk mengembangkan wawasan, pola pikir, sikap, motivasi, pengetahuan, keterampilan, serta pengalaman kewirausahaan, sehingga individu mampu menemukan ide/gagasan usaha untuk meraih peluang, memulai usaha, dan mengembangkan usaha yang dapat memberikan nilai tambah bagi dirinya dan atau orang lain. 2) Pendidikan kewirausahaan perlu dirancang secara jelas untuk mencapai tujuan pendidikan kewirausahaan berupa kompetensi kewirausahaan mahasiswa yang terdiri dari kompetensi kewirausahaan dasar, kompetensi kewirausahaan menengah, dan kompetensi kewirausahaan lanjut. 3) Isi pendidikan kewirausahaan mencakup materi untuk menciptakan, menumbuhkan, dan mengembangkan aspek afektif kewirausahaan (wawasan, 
pola pikir, sikap, motivasi), kognitif kewirausahaan (pengetahuan), dan psikomotor kewirausahaan (keterampilan) sesuai tingkat kompetensi yang akan dicapai. 4) Kegiatan dan metodenya berupa perkuliahan dan ajang praktik kreativitas untuk mencapai/menanamkan kompetensi kewirausahaan dasar; pelatihan, pembinaan, dan lomba kewirausahaan untuk mencapai kompetensi kewirausahaan menengah; serta pelatihan, pembinaan, inkubasi bisnis, dan lomba kewirausahaan universitas untuk mencapai kompetensi kewirausahaan lanjut. 5) Isi, kegiatan, dan metode pendidikan kewirausahaan berintegrasi dan bersinergi dengan mata kuliah (dosen) non-kewirausahaan; organisasi kemahasiswaan prodi/jurusan, fakultas, dan universitas; dan unit lainnya. Di tingkat prodi/jurusan, fakultas, dan universitas ada Himpunan Mahasiswa Wirausaha masing-masing.

Untuk terlaksananya desain pendidikan kewirausahaan berbasis technopreneurship ini, disarankan kepada 1) Universitas: a) Menjadikan mata kuliah kewirausahaan sebagai mata kuliah wajib (MKWU) yang dikelola oleh Unit MKWU, melalui Surat keputusan Rektor. b) Mengoptimalkan kedudukan, tugas, fungsi, dan tanggungjawab unit kewirausahaan universitas (Pusat Pengembangan Karir dan Kewirausahaan atau P2K2) untuk optimalisasi program dan pelaksanaan kewirausahaan universitas, melalui Surat Keputusan Rektor. c) Menyempurnakan organisasi kemahasiswaan agar memiliki wadah kegiatan kewirausahaan yang lebih memadai dan mengoptimalkan Koperasi Mahasiswa (Kopma) sebagai wadah dan ajang kewirausahaan mahasiswa. d) Meningkatkan kompetensi dosen kewirausahaan dan non-kewirausahaan melalui kegiatan pengembangan perkuliaahan yang mengarah pada peningkatan budaya dan praktik kewirausahaan. 2) Unit Kewirausahaan Mahasiswa Universitas: a) Menyusun grand program kewirausahaan universitas sebagai panduan penyusunan dan pelaksanaan pendidikan kewirausahaan di tingkat universitas, fakultas, prodi/jurusan, dan organisasi kegiatan kemahasiswaan, serta unit lain yang relevan. b) Menyusun/mengembangkan kurikulum pelatihan, pembinaan, inkubasi bisnis, dan lomba kewirausahaan sebagai acuan semua pihak yang berkepentingan dengan pendidikan kewirausahaan mahasiswa. c) Mengembangkan fasilitas inkubasi bisnis bagi mahasiswa agar mampu memfasilitasi untuk memulai dan menjalankan usaha serta mengembangkan usaha mahasiswa. d) Melaksanakan pelatihan, pembinaan, inkubasi, dan lomba kewirausahaan secara rutin dan reguler. 3) Fakultas: a) Membuat program dan kebijakan kewirausahaan yang mendukung program kebijakan kewirausahaan universitas berbasis bidang ilmu akademik fakultas. b) Menyelenggarakan/mendukung lomba kewirausahaan tingkat fakultas secara mandiri atau bersama Unit Kewirausahaan Universitas.

c) Memberdayakan organisasi kemahasiswaan fakultas untuk mengembangkan kewirausahaan mahasiswa fakultas. 4) Jurusan/Prodi: a) Membuat program dan kebijakan kewirausahaan yang mendukung program kebijakan kewirausahaan universitas/fakultas berbasis bidang ilmu akademikjurusan/prodi. b) Menyelenggarakan ajang kreativitas kewirausahaan tingkat jurusan/prodi. c) Memberdayakan organisasi kemahasiswaan jurusan/prodi untuk mengembangkan kewirausahaan mahasiswa jurusan/prodi. 


\section{DAFTAR RUJUKAN}

Alma, B. 2010. Kewirausahaan. Revisi. Bandung: Alfabeta.

Bondan, S. 2014. 'Koperasi Mahasiswa Sebagai Media Pembelajaran Kewirausahaan', Majalah Ilmiah Dinamika, 40(1), pp. 50-59.

Dit. Akademik Ditjen. Dikti Kemdiknas. 2008. Technopreneurship. Jakarta: Direktorat Akademik Ditjen. Pendidikan Tinggi Kemdiknas RI.

Fayolle, A. 2009. 'Entrepreneurship Education in Europe: Trends and Challenges Contents - Current trends in European entrepreneurship education'. OECD LEED Programme.

Galus, B. S. 2009. Relevansi Pendidikan Kewirausahaan Di Perguruan Tinggi, Dinas Dikpora DIY. Available at: http://www.pendidikandiy.go.id/dinas_v4/?view=v_artikel\&id=17 (Accessed: 10 April 2016).

Gasse, Y. and Tremblay, M. 2006. 'Entrepreneurship Education Among Students at a Canadian University: An Extensive Empirical Study of Students 'Entrepreneurial Preferences and Intentions', in Fayolle, A. and Klandt, H. (eds). Massachusetts: Edward Elgar Publishing, p. 1990. doi: https://doi.org/10.4337/9781847201652.00021.

Handrimurtjahjo, A. D. 2013. 'Model Pembelajaran Kewirausahaan Di Perguruan Tinggi', Jurnal Universitas Paramadina, 10(2), pp. 729-755.

Kodrat, D. S. and Christina, W. 2015. Entrepreneurship sebuah ilmu. Edited by O. M. Dwiasri and N. I. Sallama. Jakarta: Erlangga.

Pajarinen, M., Rouvinen, P. and Ylä-Anttila, P. 2006. 'Growth-orientation of nascent entrepreneurs (in Finnish with English summary)', Discussion Papers, p. 2006.

Prawirokusumo, S. 2010. Kewirausahaan dan Manajemen Usaha Kecil. Yogyakarta: BPFE-YOGYAKARTA.

Rasmussen, A., Moberg, K. and Revsbech, C. 2015 A Taxonomy of Entrepreneurship Education - Pepspectives on Goals, Teaching and Evaluation. Odense C, Denmark: The Danish Foundation for Entrepreneurship.

Sumarno and Suarman. 2017. 'Development of technopreneurship-based entrepreneurship education for students at Universitas Riau, Indonesia', International Journal of Economic Research, 14(12), pp. 65-74. 
Suparno, O. O., Hermawan, A. and Syuaib, M. F. 2008. 'Technopreneurship'. Available at: http://ono.suparno.staff.ipb.ac.id/articles/ technopreneurship-2

Suryana .2013. Kewirausahaan: Kiat dan proses Menuju Sukses. 4th edn. Jakarta: Salemba Empat.

Taatila, V. P. 2010. 'Learning entrepreneurship in higher education', Education+Training, 52(1), pp. 48-61. Available at: https://doi.org/10.1108/00400911011017672.

Undang-Undang Republik Indonesia Nomor 12 Tahun 2012 Tentang Pendidikan Tinggi. 
